\title{
Entscheidungen des
}

Obersten Gerichtshofes für die Britische Zone Herausgegeben von den

Mitgliedern des Gerichtshofes und der Staatsanwaltschaft

\section{Entscheidungen des \\ Obersten Gerichtshofes \\ für die Britische Zone}

in

Zivilsachen

\section{Band}

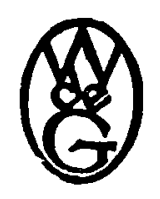

Berlin 1950

Walter de Gruyter \& Co.

vorm. G. J. Göschensche Verlagshandlung - J. Guttentag - Verlagsbuchhandlung - Georg Reimer - Karl J. Trübner -Veit \& Comp. 